\title{
Marginal Adaptation and Depth of Cure of Flowable versus Packable Bulk-fill Restorative Materials: An In Vitro Study
}

\author{
Ahmed Gamal Abdelwahed*(i), Shereen Essam (i), Monaliza M. Abdelaziz (i) \\ Department of Conservative Dentistry, Faculty of Dentistry, October 6 University, Giza, Egypt
}

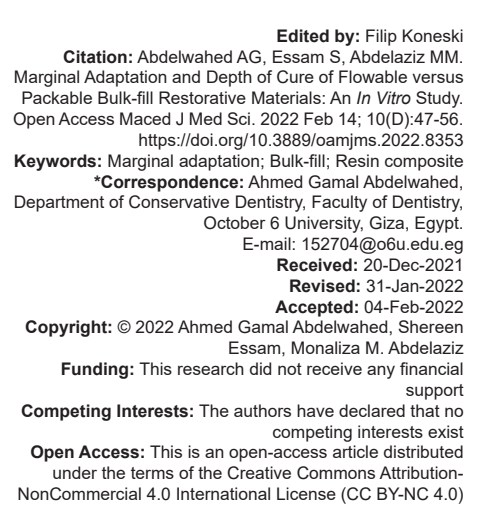

Introduction

Resin composite has become the material of choice for direct posterior restorations due to the increased demand for tooth-colored and mercuryfree restorations [1], [2], [3]. Since the innovation of resin composites, they have undergone tremendous developments in their chemistry and application techniques producing restorative materials with excellent esthetics, relative stability, and wear resistance [4], [5]. Several clinical studies reported good long-term clinical performance and acceptable survival with an average annual failure rates ranging $1-3 \%$ [2], [6], [7], [8], [9]. Despite these continuous improvements in the field of resin composite technology, they still have some disadvantages, including high coefficient of thermal expansion than that of the tooth structures, water sorption, limited depth of cure, technique sensitivity and more importantly, and polymerization shrinkage [4], [10]. The shrinkage stresses, which inevitably occur, may be transmitted to the adhesive interface [11]. This, in turn, may compromise the quality of marginal adaptation of the restoration leading to marginal leakage with subsequent sequela including postoperative sensitivity, marginal discoloration, caries adjacent to restoration (CAR), and pulpal irritation [12], [13], [14]. To overcome these catastrophic consequences and to ensure sufficient polymerization, incremental layering technique has been recommended for the placement of resin composite restorations [5], [15]. However, in deep posterior cavities, placing the restoration incrementally is time-consuming and increases the risk of contamination between successive layers or air bubbles entrapment [16].

Bulk-fill resin composites were introduced as a new class of resin composites to simplify handling, decrease restorative time, and improve clinical performance [17], [18]. They were developed by increasing the translucency and inclusion of special modulators and more sensitive photoinitiators allowing greater light to pass through the material to ensure uniform polymerization and proper degree of conversion. These modifications make the placement of 4-5-mm-thick increments feasible [19], [20]. Several bulk-fill resin composite materials are available on the market. They are classified according to their viscosity into two categories: packable (high-viscosity) and flowable (low-viscosity) [21], [22], [23], [24]. Packable 
bulk-fill resin composites contain more inorganic fillers and are much more resistant to slumping, whereas flowable bulk-fill resin composites adapt better on the cavity walls [23].

Marginal leakage accounts for over $50 \%$ of failures of resin composite restorations [25]. Thus, achieving good marginal seal is climacteric for the longterm clinical success [26]. The evaluation of marginal adaptation in Class II restorations is a common procedure for evaluating the long-term stability of resin composite restorations [27]. Several direct or indirect methods have been proposed for this purpose by using clinical or laboratory tests. Among the in vitro tests, most studies are conducted using dye penetration, and/ or scanning electron microscopic (SEM) analyses [28]. The leakage test with dye penetration represents the most frequently used method due to its simplicity. However, standardization of this process is not possible [23] Therefore, SEM analysis is considered the gold standard for observation of marginal adaptation under a wide range of magnifications especially for indirect evaluation of restorations using replicas [26], [28], [29], [30]. These replicas are usually made of epoxy resin [23] and they allow accurate investigation and comparison of approximately the same marginal segments of the restoration after applying different ageing methods [31], [32].

One of the characteristics of bulk-fill resin composites is their improved depth of cure [22]. The depth of cure along with degree of conversion of the restorative material may influence the development of stresses, which are also likely to affect the integrity of tooth-restoration interface. If the depth of cure of the resin composite is limited, it is likely to induce less polymerization shrinkage stresses around the walls and margins of the cavity which, in turn, disguise an improved marginal adaptation due to poor polymerization [33]. The depth of cure of resin composites can be assessed using a variety of different methods. In general, they can be divided in two groups. First, depth of cure can be evaluated based on the degree of conversion. Second, it can be assessed indirectly by surface hardness either by scraping method according to ISO 4049 standard or in terms of the actual microhardness value. In the latter case, the values are expressed in percent, for example, bottom-to-top hardness ratio. A ratio of 0.80 was reported to be clinically acceptable [21], [22], [34], [35], [36].

A newly emerging trend in the dental industry is the development of hybrid materials combining the advantages of glass ionomers (anticariogenic and selfadhesive properties) and resin composites (esthetics, good mechanical strength, and high bond strength) [37]. Despite the controversy regarding the classification of these materials, they are sometimes called "bioactive" due to their ionic release property [37], [38]. Giomers were introduced by incorporation of prereacted glassionomer (PRG) fillers into the resinous matrix of resin composite [39], [40]. Due to the great popularity achieved by bulk-fill resin composites, "giomer" bulk-fill restorative materials were commercially introduced [41]. Surface PRG fillers are currently incorporated in bulk-fill technologies as a high viscosity bulk-fill giomer material (BEAUTIFL-Bulk Restorative [BBR], SHOFU INC., Kyoto, Japan) and more recently, a low viscosity bulk-fill giomer material (BEAUTIFIL Flow Plus X [BFP], SHOFU INC., Kyoto, Japan). At present, the data available for these newly introduced restorative materials are limited and further laboratory investigations are required. Therefore, the aim of this in vitro study was to evaluate the marginal adaptation and depth of cure of five bulkfill restorative materials. The two null hypotheses tested were that there would be no significant differences in (1) the marginal adaptation and (2) the depth of cure of the materials under investigation.

\section{Materials and Methods}

The marginal adaptation and depth of cure of five different bulk-fill restorative materials; two flowable and three packable from different manufacturers were investigated and compared. BFP (SHOFU INC., Kyoto, Japan), PALFIQUE BULK FLOW (PBF) (Tokuyama Dental Corporation, Tokyo, Japan), BBR (SHOFU INC., Kyoto, Japan), X-tra fil (XF) (VOCO GmbH, Cuxhaven, Germany), and Filtek ${ }^{\mathrm{TM}}$ One Bulk Fill Restorative (FOB) (3M ESPE Dental Products, MN, USA) were used in this study. The restorative materials and their specification, composition, shade, lot number, and manufacturers are described in Table 1.

\section{Marginal adaptation assessment}

According to the results of a study by Campos et al. [42], sample size was determined at five teeth for each restorative material considering alpha $(\alpha)$ level of $(5 \%)$ and Beta $(\beta)$ level of $(20 \%)$, that is, power $=$ $80 \%$; therefore, a total of 25 teeth were included in the study. Sample size calculation was performed using G*Power Version 3.1.9.2. Twenty-five human maxillary premolars, which were extracted for orthodontic or periodontal reasons, with almost similar buccolingual and mesiodistal dimensions were selected from patients ranging from 18 to 40 years old. The teeth were obtained after the acquisition of patients informed content. The inclusion criteria were absence of cavities, restorations, cracks, or structural defects. Each tooth was washed with running water, brushed, scrubbed, and cleaned from any blood or soft tissue deposits. The teeth were submerged in distilled water at room temperature till their use.

Specially designed cylindrical Teflon molds of $20 \mathrm{~mm}$ height and $17 \mathrm{~mm}$ internal diameter were constructed and filled with self-curing acrylic resin 
Table 1: Materials investigated in the study and their specification, composition, shade, lot number, and manufacturers

\begin{tabular}{|c|c|c|c|c|c|c|c|c|c|}
\hline \multirow[t]{2}{*}{ Product } & \multirow[t]{2}{*}{ Abbreviation } & \multirow[t]{2}{*}{ Specification } & \multicolumn{2}{|l|}{ Composition } & \multirow{2}{*}{$\begin{array}{l}\text { Filler Wt\% } \\
\text { (Vol\%) }\end{array}$} & \multirow[t]{2}{*}{ Shade } & \multirow{2}{*}{$\begin{array}{l}\text { Polymerization } \\
\text { time (s) }\end{array}$} & \multirow{2}{*}{$\begin{array}{l}\text { Lot } \\
\text { Number }\end{array}$} & \multirow[t]{2}{*}{ Manufacturer } \\
\hline & & & Resin matrix & Fillers & & & & & \\
\hline $\begin{array}{l}\text { BEAUTIFIL } \\
\text { Flow Plus } X\end{array}$ & BFP & $\begin{array}{l}\text { Low viscosity } \\
\text { bulk-fill giomer }\end{array}$ & $\begin{array}{l}\text { Bis-GMA } \\
\text { TEGDMA } \\
\text { Bis-MPEPP }\end{array}$ & $\begin{array}{l}\text { S-PRG based on } \\
\text { fluoroboroaluminosilicate } \\
\text { glass }\end{array}$ & $72.5(51 \%)$ & $\mathrm{A} 2$ & 10 & 102036 & $\begin{array}{l}\text { SHOFU INC., } \\
\text { Kyoto, Japan }\end{array}$ \\
\hline $\begin{array}{l}\text { PALFIQUE } \\
\text { BULK FLOW }\end{array}$ & PBF & $\begin{array}{l}\text { Low viscosity } \\
\text { bulk-fill resin } \\
\text { composite }\end{array}$ & $\begin{array}{l}\text { Bis-GMA } \\
\text { TEGDMA } \\
\text { Bis-MPEPP }\end{array}$ & $\begin{array}{l}\text { Silica-Zirconia filler, } \\
\text { Composite filler }\end{array}$ & $70 \%(56 \%)$ & A2 & 10 & 064E59 & $\begin{array}{l}\text { Tokuyama Dental } \\
\text { Corporation, } \\
\text { Tokyo, Japan }\end{array}$ \\
\hline $\begin{array}{l}\text { BEAUTIFL-Bulk } \\
\text { Restorative }\end{array}$ & BBR & $\begin{array}{l}\text { High viscosity } \\
\text { bulk-fill giomer }\end{array}$ & $\begin{array}{l}\text { Bis-GMA } \\
\text { UDMA TEGDMA } \\
\text { Bis-MPEPP }\end{array}$ & S-PRG & $87 \%(74.5 \%)$ & $U$ & 10 & 031931 & $\begin{array}{l}\text { SHOFU INC., } \\
\text { Kyoto, Japan }\end{array}$ \\
\hline X-tra fil & $\mathrm{XF}$ & $\begin{array}{l}\text { High viscosity } \\
\text { bulk-fill resin } \\
\text { composite }\end{array}$ & $\begin{array}{l}\text { Bis-GMA } \\
\text { UDMA TEGDMA }\end{array}$ & $\begin{array}{l}\text { Barium boron aluminum } \\
\text { Silicate }\end{array}$ & $86 \%(70.1 \%)$ & $u$ & 10 & 2044565 & $\begin{array}{l}\text { VOCO GmbH, } \\
\text { Cuxhaven, } \\
\text { Germany }\end{array}$ \\
\hline $\begin{array}{l}\text { Filtek }^{\mathrm{TM}} \text { One } \\
\text { Bulk Fill } \\
\text { Restorative }\end{array}$ & FOB & $\begin{array}{l}\text { High viscosity } \\
\text { bulk-fill resin } \\
\text { composite }\end{array}$ & $\begin{array}{l}\text { AUDMA } \\
\text { AFM } \\
\text { Diurethane-DMA, } \\
\text { 1,12- } \\
\text { Dodecane-DMA }\end{array}$ & $\begin{array}{l}\text { Silica, Zirconia, } \\
\text { Silica-Zirconia cluster, } \\
\text { Ytterbium trifluoride }\end{array}$ & $76.5 \%$ (58.5\%) & A2 & 10 & NA51014 & $\begin{array}{l}\text { 3M ESPE Dental } \\
\text { Products, St. Paul, } \\
\text { MN, USA }\end{array}$ \\
\hline
\end{tabular}

AFM: Addition fragmentation monomers, 1,12-Dodecane-DMA.

(Acrostone Cold Cure, Acrostone, Cairo, Egypt). All the teeth were embedded vertically in the Teflon molds up to $2 \mathrm{~mm}$ under the cementoenamel junction. Standardized occlusomesial Class II cavities were prepared by single operator. All cavities were prepared above cementoenamel junction. The buccolingual width of each preparation was $2 \mathrm{~mm}$ at the occlusal part and $3.5 \mathrm{~mm}$ at the proximal part. The occlusopulpal depth was $2 \mathrm{~mm}$, while the occlusogingival depth was $4 \mathrm{~mm}$. The width of the gingival seat was $1 \mathrm{~mm}$. All enamel margins were not beveled. The accuracy of the dimensions was checked using a digital caliper (Aluminum Caliper 4", IOS Ortho, Stafford, USA). The cavities were prepared using \#330 and \#245 carbide burs (Komet ${ }^{\circledR}$, Gebr. Brasseler $\mathrm{GmbH}$ \& Co. KG, Lemgo, Germany) rotating in high speed handpiece (COMFORTdrive ${ }^{\mathrm{TM}} 200 \mathrm{XD}$, KaVo Dental, Fruehauf, Germany) with copious amount of water coolant. After every five preparations, a new set of burs was used.

The teeth then were randomly divided into five groups $(n=5)$. The prepared cavities were thoroughly rinsed and air dried. A self-etching dental adhesive (BeautiBond, SHOFU INC., Kyoto, Japan) was used. The adhesive was applied, left undisturbed for $10 \mathrm{~s}$, air dried with gentle air for $3 \mathrm{~s}$ and then dried with stronger air until a thin and uniform bonding layer was obtained. The adhesive layer was light cured using LED light curing unit (Dr's light AT CL-AT24, Good Doctors Co., Ltd., Incheon, Republic of Korea) for $5 \mathrm{~s}$ with light intensity of $1400 \mathrm{~mW} / \mathrm{cm}^{2}$ and wavelength $400-490 \mathrm{~nm}$. Light intensity was checked with a hand-held radiometer (Model 100, Kerr Corporation, California, USA). Before application of restorative materials, ultrathin celluloid band (Omni-Matrix ${ }^{\mathrm{TM}}$, Ultradent Products, Inc., St. Louis, USA) was placed to provide proper packing and contouring. Each restorative material was applied according to the manufacturer's instructions. Packable bulk-fill restorative materials were applied into the prepared cavities using gold plated composite applicator. Each restoration was contoured with fine grit finishing diamond stones (Komet ${ }^{\circledR}$, Gebr. Brasseler $\mathrm{GmbH}$ and Co. KG, Lemgo, Germany) and was polished with fine $(24 \mu \mathrm{m})$ and superfine $(8 \mu \mathrm{m}) \mathrm{Al}_{2} \mathrm{O}_{3}$ discs (Sof-Lex ${ }^{\mathrm{TM}}$ discs, 3M ESPE Dental Products, MN, USA) mounted in a low speed hand piece (FX22, NSK, Tochigi, Japan) for $20 \mathrm{~s}$.

For evaluation of marginal adaptation, impressions of the restored teeth were taken using polyether impression material (Impregum $^{\mathrm{TM}}$ Soft Polyether Impression Material, 3M ESPE Dental Products, MN, USA) and then poured with epoxy resin (Kemapoxy 150, CMB International, Giza, Egypt) to obtain epoxy replicas. All cavity margins were analyzed by SEM (Model Quanta ${ }^{\text {TM }} 250$ FEG, FEI Company, Oregon, USA) attached with EDX Unit (Energy Dispersive X-ray Analyses), with accelerating voltage $30 \mathrm{~K} . \mathrm{V}$. at a magnification of $200 \times$. The values are expressed as a percentage of the continuous margin over the total margin length for the occlusal and proximal margins (Figures 1 and 2). The marginal analyses were carried out by one evaluator experienced with quantitative margin analysis who was blinded to the groups.

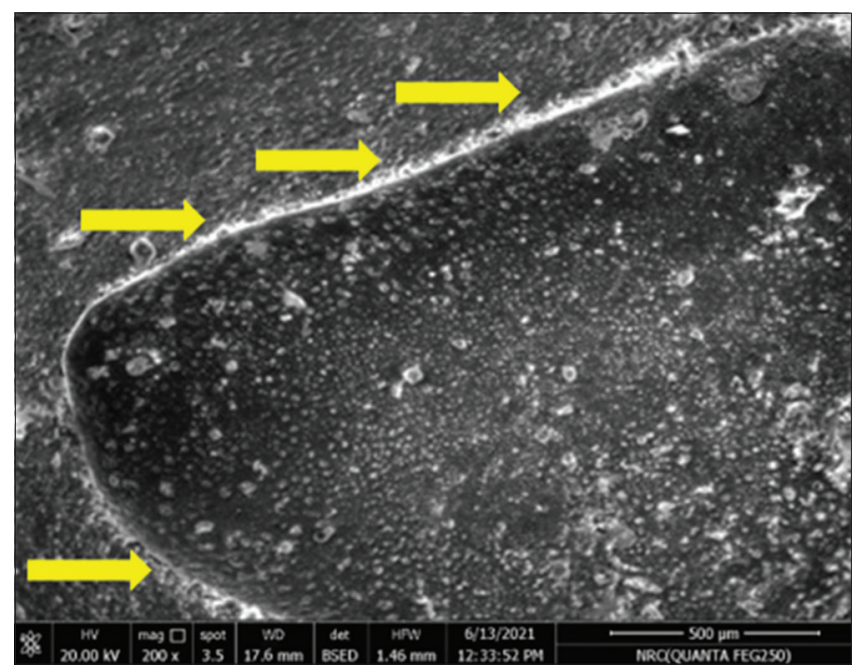

Figure 1: Representative scanning electron microscopic 200× image of continuous margins at the occlusal surface (yellow arrows)

All teeth were artificially aged by thermal cycling. The teeth were subjected to 2500 cycles in a thermocycling device (THE-1100 Thermocycler, SD 


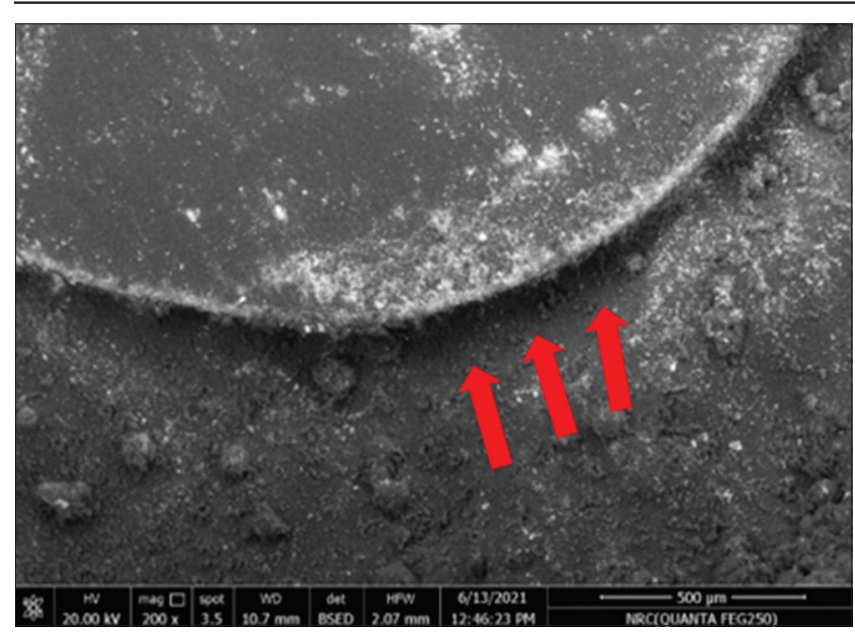

Figure 2: Representative scanning electron microscopic 200× image of discontinuous margins at the proximal surface (red arrows)

Mechatronik, Feldkirchen-Westerham, Germany) with water baths between $5^{\circ} \mathrm{C}$ and $55^{\circ} \mathrm{C}$ with a dwell time of $30 \mathrm{~s}$ in each bath and a transfer time of $5 \mathrm{~s}$ between each bath. After thermocycling, new epoxy replicas were obtained and examined as abovementioned.

\section{Depth of cure by Vickers microhardness}

Sample size was calculated based on the results of a study by Jang et al. [43]. Using alpha $(\alpha)$ level of $(5 \%)$ and Beta $(\beta)$ level of $(20 \%)$, that is, power $=$ $80 \%$; the minimum estimated sample size was 10 disks per group. A split Teflon ring with an external diameter of $40 \mathrm{~mm}$ and internal diameter of $4 \mathrm{~mm}$ was used to prepare disks of restorative materials with $4 \mathrm{~mm}$ height. The Teflon ring was placed on top of a glass slap, and then each restorative material was applied inside the ring. A celluloid strip was placed on the Teflon ring and another glass slap was placed with slight pressure to produce a flat and smooth top surface of the disks. The disks were light cured by placing the tip of the light curing unit directly perpendicular on the celluloid strip. The upper and lower surfaces of each disk were polished with 2000-grit SiC after being removed from the split ring. The disks were then stored for $24 \mathrm{~h}$ at room temperature in dry and dark conditions.

A microhardness tester (Wilson $^{\circledR}$ Tukon $^{\mathrm{TM}}$ 1102/1202, BUEHLER, Illinois, USA) was used to measure Vickers microhardness of the top and bottom surfaces of each disk. For these measurements, a $500 \mathrm{~g}$ force was applied for $5 \mathrm{~s}$ and three points were measured for each surface. The three readings were averaged to obtain a single value for each surface. The bottom-to-top surface microhardness ratio was calculated. A 0.80 ratio indicates adequate depth of cure.

\section{Statistical methods}

Numerical data were represented as mean and standard deviation (SD) values. Shapiro-Wilk's test was used to test for normality. Homogeneity of variances was tested using Levene's test. Data were parametric and showed variance homogeneity. One-way analysis of variance test followed by Tukey's post-hoc test was used to study different intergroup comparisons. The significance level was set at $p<0.05$ within all tests. Statistical analysis was performed with IBM ${ }^{\circledR}$ SPSS $^{\circledR}$ Statistics Version 26 for Windows.

\section{Results}

\section{Marginal adaptation}

Results of inter and intragroup comparisons for marginal adaptation are presented in Table 2 and Figure 3 . The results showed that there was no significant difference between different groups before $(p=0.398)$ and after $(p=0.644)$ thermocycling. Before thermocycling, the highest value was found in BFP group $(94.81 \pm 2.13)$, followed by PBF $(94.24 \pm 3.21)$, then BBR (92.69 \pm 3.00$)$, and FOB (92.52 \pm 3.33$)$, while the lowest value was found in XF group (91.63 \pm 2.30). After thermocycling, the highest value was found in BFP group $(80.45 \pm 2.87)$, followed by XF $(79.41$ $\pm 2.51)$, then FOB $(78.33 \pm 3.98)$, and PBF (78.32 \pm 2.94 ), while the lowest value was found in BBR group $(77.39 \pm 3.95)$. Within all groups, there was a significant decrease in marginal adaptation after thermocycling $(p<0.001)$.

\section{Depth of cure}

Results of intergroup comparison for bottomto-top ratio are presented in Table 3 and Figure 4. The results showed that there was a significant difference between different groups $(p<0.001)$. The highest value was found in BFP group (0.97 \pm 0.02$)$, followed by PBF $(0.93 \pm 0.04)$, then XF $(0.89 \pm 0.05)$, and FOB $(0.86 \pm$ $0.08)$, while the lowest value was found in BBR group $(0.81 \pm 0.11)$. Post hoc pairwise comparisons showed

Table 2: Inter and intragroup comparisons for marginal adaptation (\%) before and after thermocycling

\begin{tabular}{|c|c|c|c|c|c|c|}
\hline \multirow[t]{2}{*}{ Thermocycling } & \multicolumn{5}{|c|}{ Marginal adaptation (\%) (Mean \pm SD) } & \multirow[t]{2}{*}{$\mathrm{p}$-value } \\
\hline & (BFP) & (PBF) & (BBR) & (XF) & (FOB) & \\
\hline Before & $94.81 \pm 2.13$ & $94.24 \pm 3.21$ & $92.69 \pm 3.00$ & $91.63 \pm 2.30$ & $92.52 \pm 3.33$ & 0.398 \\
\hline After & $80.45 \pm 2.87$ & $78.32 \pm 2.94$ & $77.39 \pm 3.95$ & $79.41 \pm 2.51$ & $78.33 \pm 3.98$ & 0.644 \\
\hline $\mathrm{p}$-value & $<0.001^{*}$ & $<0.001^{*}$ & $<0.001^{*}$ & $<0.001^{*}$ & $<0.001^{*}$ & \\
\hline
\end{tabular}




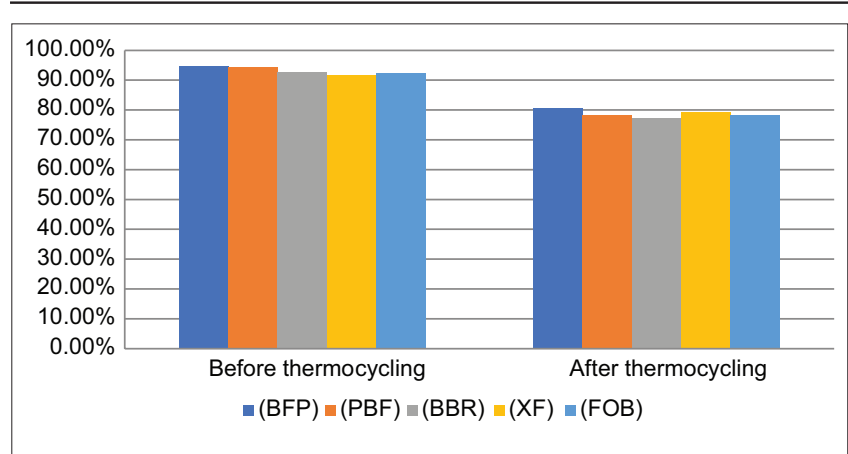

Figure 3: Bar chart showing average marginal adaptation (\%) before and after thermocycling

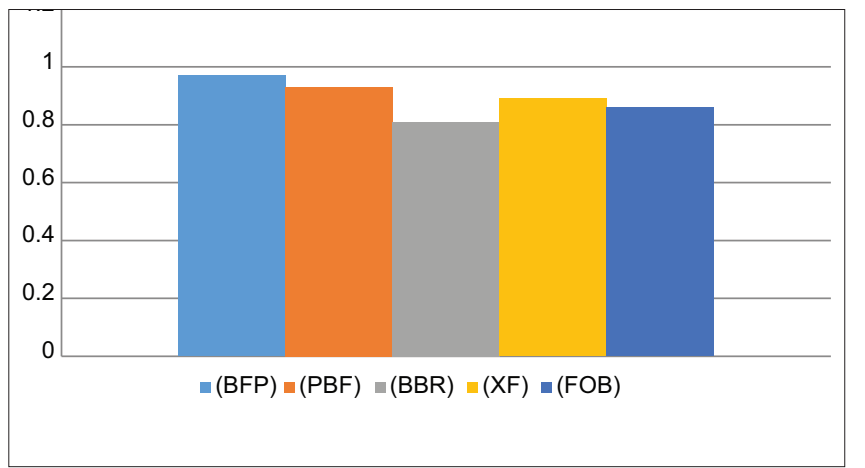

Figure 4: Bar chart showing average depth of cure (bottom-to-top ratio)

BFP to have a significantly higher value than all other groups except for (PBF) $(p<0.001)$.

Table 3: Intergroup comparisons for depth of cure (Bottom-to-top ratio)

\begin{tabular}{ll}
\hline Depth of cure (Bottom-to-top ratio) (Mean \pm SD) & p-value
\end{tabular}

\begin{tabular}{lllll}
\hline (BFP) & (PBF) & (BBR) & (XF) & (FOB
\end{tabular}

\begin{tabular}{llllll}
\hline $0.97 \pm 0.02^{\mathrm{A}}$ & $0.93 \pm 0.04^{\mathrm{AB}}$ & $0.81 \pm 0.11^{\mathrm{B}}$ & $0.89 \pm 0.05^{\mathrm{B}}$ & $0.86 \pm 0.08^{\mathrm{B}}$ & $<0.001^{*}$
\end{tabular} Different superscript letters indicate a statistically significant difference within the same horizontal row; *significant $(p<0.05)$, BFP: BEAUTIFIL flow plus X, PBF: PALFIQUE BULK FLOW, BBR: BEAUTIFL-bulk restorative, XF: X-tra fil, FOB: Filtek ${ }^{T M}$ one bulk fill restorative.

\section{Discussion}

Bulk-fill resin composites were introduced to shorten application time and to overcome the complications associated with incremental application technique [3]. The polymerization effectiveness of these materials has been questioned to guarantee adequate biocompatibility and mechanical properties and to decrease the risk of postoperative sensitivity to avoid early restoration failure [44]. This study focused on two of the aspects related to polymerization effectiveness: marginal adaptation and depth of cure. Proper marginal adaptation and absence of marginal leakage are core issues for the longevity of any restoration especially in the cervical margins of Class II cavities where the problem of microleakage becomes more pronounced [23], [45], [46], [47].

The results of present study showed that all investigated materials exhibited satisfactory marginal adaptation before thermal cycling. Unfortunately, the level of marginal adaptation was not maintained after thermal cycling. There were no significant differences between different groups before and after thermocycling. Both flowable and packable bulk-fill resin composites showed similar marginal adaptation; therefore, the first null hypothesis was accepted. It could be argued that no significant difference was observed due to small sample size which is insufficient to detect differences between investigated materials. However, the sample size was chosen based on the results of a previous study by Campos et al. [42]. The marginal adaptation was expressed as a percentage of the continuous margins for the total judgeable margin length [24], [42]. Measuring the total length of marginal gap, rather than the width, is a valid method for analyzing the quality of marginal adaptation of resin composite restorations [28]. Based on SEM results, it was noticed that none of the groups could provide $100 \%$ continuous margins, regardless of the type of restorative material used. Discontinuous restoration margins may lead to CAR or loss of retention [24]. Two factors related to the resin composite are of key importance to marginal adaptation: polymerization shrinkage stress and elastic modulus. The lower elastic modulus of bulkfill resin composites improves their adaptation to cavity walls [4]. The marginal adaptation of bulk-fill resin composites has been reported to be materialdependent [24], [46]. However, shrinkage stress is not a material's property. C-factor is among other several factors affecting the shrinkage stress [11]. In this study standardized Class II cavities were prepared with nearly similar dimensions; therefore, the $\mathrm{C}$-factor was almost the same in all restorations. As previously described; marginal gaps may develop as a sequalae of polymerization shrinkage stresses if the shrinkage forces of the resin composite exceed the bond strength [24]. In this study, the self-etching dental adhesive (BeautiBond) was selected because it showed reliable results in both in vitro [48], [49] and clinical studies [50].

Reduction of shrinkage stress is an important feature of bulk-fill resin composites [51]. Though advertised as a new material class, most bulk-fill resin composites available in the market seem to have no significant modification in their chemical composition from conventional microhybrid and nanohybrid resin composites. They contain monomers such as Bisphenol A dimethacrylate (BisGMA), Triethylene glycol dimethacrylate (TEGDMA), and Urethane dimethacrylate in their organic matrix in addition to regular filler systems [51], [52]. Manufactures adopted different strategies to achieve sufficient polymerization and to reduce shrinkage stress [53]. These strategies involve using additional or more efficient photoinitiators [54] and addition of low shrink monomers, pre-polymerized fillers, or stress-relieving additives [14]. Other strategies focus 
on increasing light transmission by using fillers and monomers with similar refractive index and reducing filler content [55], [56].

The results of the present study coincide with conclusion of a recent systematic review by Gerula-Szymańska et al., [23] who concluded that the marginal adaptation of flowable and packable bulk-fill resin composites are similar when used for Class II restorations. In contrast to these findings, Paganini et al., [24] reported that packable bulk-fill resin composites showed higher margin integrities compared with the flowable ones. The inconsistency between the results of the abovementioned study and the present study can be attributed to the differences in investigated bulk-fill restorative materials and testing protocol variations. The aging procedures were different between the two studies. The teeth were subjected to 1000 thermal cycles (between $5^{\circ} \mathrm{C}$ and $50^{\circ} \mathrm{C}$ ) and 400,000 mechanical loading cycles while in our study the teeth were subjected 2500 thermal cycles (between $5^{\circ} \mathrm{C}$ and $55^{\circ} \mathrm{C}$ ). It is noteworthy that elastic modulus of restorative materials determines their behavior under stress [42]. The elastic modulus was reported to be more important than the amount of shrinkage in determining the stress [57], [58]. Consequently, the high volumetric shrinkage produced by flowable bulk-fill resin composites can be compensated by the low elastic modulus, thus the stress buildup is reduced, and the marginal integrity is maintained [59]

A major concern regarding bulk-fill resin composites is whether the resin composite cures properly in the deeper portions of the restoration [42]. Inadequate curing of resin composites results in increased free monomers which are cytotoxic to the pulp and deteriorate the physicomechanical properties of the restoration [60]. According to the conclusions of the systematic review by Lima et al., [44] most of the studies investigating the depth of cure of bulk-fill resin composites reported material-dependent results. Several factors may affect the depth of cure of bulkfill resin composites. These factors include curing light time and intensity as well as resin chemical composition and most importantly fillers size, type, and volume [60]. The shade of bulk-fill resin composites influences their depth of cure [61]. In the present study, a light shade was selected for each material (shade A2, except for BBR and XF, which was a universal shade) to confirm that the effect of shading pigments would not be a confounding variable and to guarantee optimal light penetration through the restorations.

Depth of cure can be judged by determining microhardness ratio. If the bottom-to-top hardness ratio is 0.8 or more, an acceptable curing depth is achieved [20], [34]. In the present study, the bottomto-top hardness ratio exceeded 0.8 in all bulk-fill restorative materials. However, the second null hypothesis was rejected because the depth of cure values showed significant differences between different groups. Flowable bulk-fill restorative materials (BFP and $\mathrm{PBF}$ ) recorded higher values in comparison with packable ones (BBR, XF, and FOB). These results are in line with the results of the previous studies [20], [21], [61] that reported greater depth of cure in flowable bulkfill resin composites compared to packable ones. This could be attributed to the lower percentage of inorganic fillers in investigated flowable bulk-fill restorative materials, ranging between 70 and 72.5 wt $\% / 51$ and $56 \mathrm{vol} \%$. In contrast to packable bulk-fill restorative materials which range between 76.5 and 87 wt\%/58.5 and $74.5 \mathrm{vol} \%$. The lower filler content in flowable bulk-fill restorative materials results in higher resin to filler ratio and a reduction in filler-matrix interface and light scattering leading to better light penetration and higher degree of conversion [20], [34]. Furthermore, the greater amount of organic matrix in flowable bulkfill materials is an important factor causing higher depth of cure. It should be emphasized that low-molecular weight monomers such as TEGDMA and Bisphenol A polyethoxy methacrylate (Bis-MPEPP), which are the main constituents of the organic matrix, have higher reactivity and flexibility allowing increased formation of binding sites during light curing process, thus, enhancing the degree of conversion and increasing polymerization efficiency [44].

The resin matrix of giomers does not seem to differ from that contained in the resin composite being mainly constituted from Bis-GMA, TEGDMA, Bis-MPEPP and other monomers [37], [62]. Therefore, their polymerization efficiency is nearly like resin composites. A similar conclusion was reached by Ilie and Fleming [39]. They, too, concluded that flowable and packable giomer bulk-fill restorative materials showed an adequate depth of cure of $>4 \mathrm{~mm}$. On the other hand, some studies [60], [63], [64] reported that giomer bulk-fill restoratives were not able to achieve a depth of cure of $4 \mathrm{~mm}$. Variations in results can be related to differences in study design regarding hardness testing conducted (Vickers vs. Knoop), hardness testing protocols and specimen mold material. Yap et al. [60] in their study assessed the depth of cure using Knoop hardness number $(\mathrm{KHN})$. $\mathrm{KHN}$ was reported to be lower at or near the mold walls than at the center due to non-uniform distribution of KHN within molds [65]. Although Singla et al. [63] measured the depth of cure using Vickers hardness number as done in the present study, they reported different findings. This could be attributed to the difference in mold material (metallic versus Teflon). Metallic molds do not accurately reflect the depth of cure obtained clinically because they have different optical properties than tooth structure. Light transmittance through translucent tooth structure, may enhance the depth of cure of resin composites like the increased depth of cure reported with Teflon molds [54]. Tsujimoto et al. determined the depth of cure by the ISO 4049 scraping method. The reliability of scraping method was criticized because it is a subjective method 
which may be affected by inter-operator differences in addition to difficulty to standardize the procedure of scraping off the uncured restorative material [20], [21].

Although in vitro testing of restorative materials provides an important initial screening for their properties, the obtained results can not accurately predict the clinical performance of restorations [66]. To mimic the influence of oral environment, the restorations in the present study were subjected to thermal ageing. Thermocycling is a valid in vitro method to simulate the thermal changes caused by drinking, eating, and breathing. However, there is no one standard protocol for thermocycling. Thermocycling regimens differ greatly. There is no agreement on the optimum number of cycles, temperature range, and dwell time [67]. Furthermore, a great contradictory exists between studies assessing microhardness regarding the indentation load and speed [68]. Hence, further laboratory and randomized clinical trials of bulk-fill restorative materials remain mandatory while overcoming the abovementioned limitations in the present study.

\section{Conclusions}

Based on the conditions and limitations of this in vitro study, it is possible to conclude that:

1. All investigated materials showed accepted marginal adaptation in Class II restorations

2. $100 \%$ perfect margins could not be achieved in any group

3. Thermocycling had detrimental effects on marginal adaptation

4. The 4-mm depth of cure of all investigated materials was acceptable ( $>0.80$ bottom-to-top ratio)

5. Flowable bulk-fill restorative materials (BFP and PBF) showed statistically significant higher depth of cure values than packable ones (BBR, $\mathrm{XF}$, and $\mathrm{FOB}$ )

6. The marginal adaptation and depth of cure of bulk-fill giomers are acceptable and comparable to their resin composites counterparts.

\section{References}

1. Haak R, Näke T, Park KJ, Ziebolz D, Krause F, Schneider H. Internal and marginal adaptation of high-viscosity bulk-fill composites in Class II cavities placed with different adhesive strategies. Odontology. 2019;107(3):374-82. https://doi. org/10.1007/s10266-018-0402-1

2. Frankenberger $R$, Reinelt $C$, Glatthöfer $C$, Krämer $N$. Clinical performance and SEM marginal quality of extended posterior resin composite restorations after 12 years.
Dent Mater. 2020;36(7):e217-28. https://doi.org/10.1016/j. dental.2020.03.022

PMid:32451207

3. Yazici AR, Kutuk ZB, Ergin E, Karahan S, Antonson SA. Sixyear clinical evaluation of bulk-fill and nanofill resin composite restorations. Clin Oral Investig. 2022;26(1):417-26. https://doi. org/10.1007/s00784-021-04015-2

PMid:34110494

4. Peutzfeldt A, Mühlebach S, Lussi A, Flury S. Marginal gap formation in approximal "bulk fill" resin composite restorations after artificial ageing. Oper Dent. 2018;43(2):180-9. https://doi. org/10.2341/17-068-L

PMid:29148914

5. Al-Nahedh HN, Alawami Z. Fracture resistance and marginal adaptation of capped and uncapped bulk-fill resin-based materials. Oper Dent. 2020;45(2):E43-56. https://doi. org/10.2341/17-367-L

PMid:31750801

6. Opdam NJ, Bronkhorst EM, Roeters JM, Loomans BA A retrospective clinical study on longevity of posterior composite and amalgam restorations. Dent Mater. 2007;23(1):2-8. https:// doi.org/10.1016/j.dental.2005.11.036

PMid:16417916

7. Da Rosa Rodolpho PA, Donassollo TA, Cenci MS, Loguércio AD, Moraes RR, Bronkhorst EM, et al. 22-Year clinical evaluation of the performance of two posterior composites with different filler characteristics. Dent Mater. 2011;27(10):955-63. https://doi. org/10.1016/j.dental.2011.06.001

PMid:21762980

8. van Dijken JW, Pallesen U. A randomized 10-year prospective follow-up of Class II nanohybrid and conventional hybrid resin composite restorations. J Adhes Dent. 2014;16(6):585-92. https://doi.org/10.3290/j.jad.a33202

PMid:25516885

9. van Dijken JW, Lindberg A. A 15-year randomized controlled study of a reduced shrinkage stress resin composite. Dent Mater. 2015;31(9):1150-8. https://doi.org/10.1016/j.dental.2015.06.012 PMid:26205382

10. Oskoee SS, Bahari M, Navimipour EJ, Ajami AA, Ghiasvand N, Oskoee AS. Factors affecting marginal integrity of Class II bulk-fill composite resin restorations. J Dent Res Dent Clin Dent Prospects. 2017;11(2):101-9. https://doi.org/10.15171/ joddd.2017.019

PMid:28748051

11. Ferracane JL. Developing a more complete understanding of stresses produced in dental composites during polymerization. Dent Mater. 2005;21(1):36-42. https://doi.org/10.1016/j. dental.2004.10.004

PMid: 15681000.

12. Mantri SP, Mantri SS. Management of shrinkage stresses in direct restorative light-cured composites: A review. J Esthet Restor Dent. 2013;25(5):305-13. https://doi.org/10.1111/ jerd.12047

PMid:24148979

13. Kaisarly D, Gezawi ME. Polymerization shrinkage assessment of dental resin composites: A literature review. Odontology. 2016;104(3):257-70. https://doi.org/10.1007/ s10266-016-0264-3

PMid:27540733

14. Soares CJ, Faria-E-Silva AL, Rodrigues MP, Vilela ABF, Pfeifer CS, Tantbirojn D, et al. Polymerization shrinkage stress of composite resins and resin cements-what do we need to know? Braz Oral Res. 2017;31 Suppl 1:e62. https://doi. org/10.1590/1807-3107BOR-2017.vol31.0062 


\section{PMid:28902242}

15. Veloso SR, Lemos CA, de Moraes SL, do Egito Vasconcelos BC, Pellizzer EP, de Melo Monteiro GQ. Clinical performance of bulk-fill and conventional resin composite restorations in posterior teeth: A systematic review and meta-analysis. Clin Oral Investig. 2019;23(1):221-33. https://doi.org/10.1007/ s00784-018-2429-7

PMid:29594349

16. Arbildo-Vega HI, Lapinska B, Panda S, Lamas-Lara C, Khan AS, Lukomska-Szymanska M. Clinical effectiveness of bulk-fill and conventional resin composite restorations: Systematic review and meta-analysis. Polymers (Basel). 2020;12(8):1786. https:// doi.org/10.3390/polym12081786

PMid:32785019

17. Bellinaso MD, Soares FZM, Rocha RO. Do bulk-fill resins decrease the restorative time in posterior teeth? A systematic review and meta-analysis of in vitro studies. J Investig Clin Dent. 2019;10(4):e12463. https://doi.org/10.1111/jicd.12463 PMid:31560449

18. Berti LS, Turssi CP, Amaral FL, Basting RT, Junqueira JLC, Panzarella FK, et al. Clinical and radiographic evaluation of high viscosity bulk-fill resin composite restorations. Am J Dent. 2020;33(4):213-7.

PMid:32794397

19. Yu P, Yap A, Wang XY. Degree of conversion and polymerization shrinkage of bulk-fill resin-based composites. Oper Dent. 2017;42(1):82-9. https://doi.org/10.2341/16-027-L PMid:28002693

20. Ajaj RA, Farsi NJ, Alzain L, Nuwaylati N, Ghurab R, Nassar HM. Dental bulk-fill resin composites polymerization efficiency: A systematic review and meta-analysis. J Comp Sci. 2021;5(6):149. https://doi.org/10.3390/jcs5060149

21. Reis AF, Vestphal M, Amaral RC, Rodrigues JA, Roulet JF, Roscoe MG. Efficiency of polymerization of bulk-fill composite resins: Asystematic review. Braz Oral Res. 2017;31 Suppl 1:e59. https://doi.org/10.1590/1807-3107BOR-2017.vol31.0059 PMid:28902239

22. van Ende A, De Munck J, Lise DP, van Meerbeek B. Bulk-fil composites: A review of the current literature. J Adhes Dent. 2017;19(2):95-109. https://doi.org/10.3290/j.jad.a38141 PMid:28443833

23. Gerula-Szymańska A, Kaczor K, Lewusz-Butkiewicz K, Nowicka A. Marginal integrity of flowable and packable bulk fill materials used for Class II restorations-a systematic review and meta-analysis of in vitro studies. Dent Mater J. 2020;39(3):335-44. https://doi.org/10.4012/dmj.2018-180 PMid:31932546

24. Paganini A, Attin T, Tauböck TT. Margin integrity of bulk-fill composite restorations in primary teeth. Materials (Basel). 2020;13(17):3802. https://doi.org/10.3390/ma13173802 PMid:32872141

25. Rengo C, Goracci C, Ametrano G, Chieffi N, Spagnuolo G, Rengo S, et al. Marginal leakage of class $\mathrm{V}$ composite restorations assessed using microcomputed tomography and scanning electron microscope. Oper Dent. 2015;40(4):440-8. https://doi.org/10.2341/14-022-L PMid:25602350

26. Haak R, Brückner A, Häfer M, Scholz M, Schneider H. Is there an association between clinical and SEM quantitative marginal analysis in a 90-month trial? J Adhes Dent. 2021;23(1):37-46. https://doi.org/10.3290/j.jad.b916821

PMid:33512114

27. Tosco V, Vitiello F, Furlani M, Gatto ML, Monterubbianesi R, Giuliani A, et al. Microleakage analysis of different bulk-filling techniques for Class II restorations: $\mu-C T$, SEM and EDS evaluations. Materials (Basel). 2020;14(1):31. https://doi. org/10.3390/ma14010031

PMid:33374708

28. Ramić BD, Stojanac IL, Drobac MR, Kantardžić IR, Maletin AZ, Cvjetićanin MT, et al. Application of scanning electron microscopy in the observation of dentin-adhesive interface. Microsc Res Tech. 2021;84(4):602-7. https://doi.org/10.1002/ jemt.23618

PMid:33044003

29. Carrera CA, Lan C, Escobar-Sanabria D, Li Y, Rudney J, Aparicio C, et al. The use of micro-CT with image segmentation to quantify leakage in dental restorations. Dent Mater. 2015;31(4):382-90. https://doi.org/10.1016/j.dental.2015.01.002 PMid:25649496

30. Ramic BD, Drobac MR, Stojanac IL, Premovic MT, Petrovic LM. The micromorphological characterization of adhesive bond in dentin different locations. Microsc Res Tech. 2018;81(1):33-7. https://doi.org/10.1002/jemt.22953

PMid:28987026

31. Heintze SD. Systematic reviews: I. The correlation between laboratory tests on marginal quality and bond strength. II. The correlation between marginal quality and clinical outcome. J Adhes Dent. 2007;9 Suppl 1:77-106.

PMid:18341236

32. Heintze SD. Clinical relevance of tests on bond strength microleakage and marginal adaptation. Dent Mater. 2013;29(1):59-84. https://doi.org/10.1016/j.dental.2012.07.158 PMid:22920539

33. Benetti AR, Havndrup-Pedersen C, Honoré D, Pedersen MK Pallesen U. Bulk-fill resin composites: Polymerization contraction, depth of cure, and gap formation. Oper Dent. 2015;40(2):190-200. https://doi.org/10.2341/13-324-L PMid:25216940

34. Bouschlicher MR, Rueggeberg FA, Wilson BM. Correlation of bottom-to-top surface microhardness and conversion ratios for a variety of resin composite compositions. Oper Dent. 2004;29(6):698-704.

PMid:15646227

35. Moore BK, Platt JA, Borges G, Chu TM, Katsilieri I. Depth of cure of dental resin composites: ISO 4049 depth and microhardness of types of materials and shades. Oper Dent. 2008;33(4):408-12. https://doi.org/10.2341/07-104 PMid:18666498

36. Garcia D, Yaman P, Dennison J, Neiva G. Polymerization shrinkage and depth of cure of bulk fill flowable composite resins. Oper Dent. 2014;39(4):441-8. https://doi.org/10.2341/12-484-L PMid:24304339

37. Francois P, Fouquet V, Attal JP, Dursun E. Commercially available fluoride-releasing restorative materials: A review and a proposal for classification. Materials (Basel). 2020;13(10):2313. https://doi.org/10.3390/ma13102313 PMid:32443424

38. Vallittu PK, Boccaccini AR, Hupa L, Watts DC. Bioactive denta materials-Do they exist and what does bioactivity mean? Dent Mater. 2018;34(5):693-4. https://doi.org/10.1016/j. dental.2018.03.001 PMid:29571660.

39. Ilie N, Fleming GJ. In vitro comparison of polymerisation kinetics and the micro-mechanical properties of low and high viscosity giomers and RBC materials. J Dent. 2015;43(7):814-22. https:// doi.org/10.1016/j.jdent.2015.04.009 PMid:25930017

40. Rusnac ME, Gasparik C, Irimie AI, Grecu AG, Mesaroş AŞ, 
Dudea D. Giomers in dentistry-at the boundary between dental composites and glass-ionomers. Med Pharm Rep. 2019;92(2):123-8. https://doi.org/10.15386/mpr-1169 PMid:31086838

41. Ilie N. High viscosity bulk-fill giomer and ormocer-based resin composites: An in-vitro comparison of their mechanical behaviour. Stoma EDU J. 2016;3(1):54-62.

42. Campos EA, Ardu S, Lefever D, Jassé FF, Bortolotto T, Krejci I. Marginal adaptation of Class II cavities restored with bulk-fill composites. J Dent. 2014;42(5):575-81. https://doi. org/10.1016/j.jdent.2014.02.007

PMid:24561041

43. Jang $\mathrm{JH}$, Park $\mathrm{SH}$, Hwang IN. Polymerization shrinkage and depth of cure of bulk-fill resin composites and highly filled flowable resin. Oper Dent. 2015;40(2):172-80. https://doi. org/10.2341/13-307-L

PMid:25136904

44. Lima RB, Troconis CC, Moreno MB, Murillo-Gómez F, de Goes MF. Depth of cure of bulk fill resin composites: A systematic review. J Esthet Restor Dent. 2018;30(6):492-501. https://doi.org/10.1111/jerd.12394

PMid:30375146

45. Al-Harbi F, Kaisarly D, Bader D, El Gezawi M. Marginal integrity of bulk versus incremental fill Class II composite restorations. Oper Dent. 2016;41(2):146-56. https://doi.org/10.2341/14-306-L PMid:26266653

46. Patel MC, Bhatt RK, Makwani DA, Dave LD, Raj VS. Comparative evaluation of marginal seal integrity of three bulkfill composite materials in Class II cavities: An in vitro study. Adv Hum Biol. 2018;8:201-5. Available from: https://www.aihbonline. com/text.asp?2018/8/3/201/241923

47. Yantcheva SM. Marginal adaptation and micropermeability of Class II cavities restored with three different types of resin composites-a comparative ten-month in vitro study. Polymers (Basel). 2021;13(10):1660. https://doi.org/10.3390/ polym13101660

PMid:34065229

48. Hashimoto M, Fujita S, Endo K, Ohno H. In vitro degradation of resin-dentin bonds with one-bottle self-etching adhesives. Eur J Oral Sci. 2009;117(5):611-7. https://doi. org/10.1111/j.1600-0722.2009.00664.x PMid: 19758260

49. Bacelar-Sá R, Sauro S, Abuna G, Vitti R, Nikaido T, Tagami J, et al. Adhesion evaluation of dentin sealing, micropermeability, and bond strength of current HEMA-free adhesives to dentin. J Adhes Dent. 2017;19(4):357-64. https://doi.org/10.3290/j.jad. a38866

\section{PMid:28849795}

50. Kurokawa H, Takamizawa T, Rikuta A, Tsubota K, Miyazaki M. Three-year clinical evaluation of posterior composite restorations placed with a single-step self-etch adhesive. J Oral Sci. 2015;57(2):101-8. https://doi.org/10.2334/josnusd.57.101 PMid:26062858

51. Alshali RZ, Salim NA, Sung R, Satterthwaite JD, Silikas N. Qualitative and quantitative characterization of monomers of uncured bulk-fill and conventional resin-composites using liquid chromatography/mass spectrometry. Dent Mater. 2015;31(6):711-20. https://doi.org/10.1016/j.dental.2015.03.010 PMid:25882276

52. Ilie N, Bucuta S, Draenert M. Bulk-fill resin-based composites: An in vitro assessment of their mechanical performance. Oper Dent. 2013;38(6):618-25. https://doi.org/10.2341/12-395-L PMid:23570302

53. Al Sunbul H, Silikas N, Watts DC. Polymerization shrinkage kinetics and shrinkage-stress in dental resin-composites. Dent Mater. 2016;32(8):998-1006. https://doi.org/10.1016/j. dental.2016.05.006

\section{PMid:27240744}

54. Menees TS, Lin CP, Kojic DD, Burgess JO, Lawson NC. Depth of cure of bulk fill composites with monowave and polywave curing lights. Am J Dent. 2015;28(6):357-61.

PMid:26897758

55. Shortall AC, Palin WM, Burtscher P. Refractive index mismatch and monomer reactivity influence composite curing depth. J Dent Res. 2008;87(1):84-8. https://doi. org/10.1177/154405910808700115

PMid: 18096900

56. Fujita K, Ikemi T, Nishiyama N. Effects of particle size of silica filler on polymerization conversion in a light-curing resin composite. Dent Mater. 2011;27(11):1079-85. https://doi. org/10.1016/j.dental.2011.07.010

PMid:21824650

57. Ferracane JL. Buonocore Lecture. Placing dental composites-a stressful experience. Oper Dent. 2008;33(3):247-57. https://doi. org/10.2341/07-BL2

PMid: 18505214

58. Park J, Chang J, Ferracane J, Lee IB. How should composite be layered to reduce shrinkage stress: Incremental or bulk filling? Dent Mater. 2008;24(11):1501-5. https://doi.org/10.1016/j. dental.2008.03.013

PMid: 18433857

59. Braga RR, Hilton TJ, Ferracane JL. Contraction stress of flowable composite materials and their efficacy as stressrelieving layers. J Am Dent Assoc. 2003;134(6):721-8. https:// doi.org/10.14219/jada.archive.2003.0258 PMid:12839408

60. Yap AU, Pandya M, Toh WS. Depth of cure of contemporary bulkfill resin-based composites. Dent Mater J. 2016;35(3):503-10. https://doi.org/10.4012/dmj.2015-402 PMid:27252008

61. Rooz MN, Jordehi AY. The effect of shade and thickness on the depth of cure of bulk-fill composites with different viscosities. J Dent (Shiraz). 2020;21(4):322-9. https://doi.org/10.30476/ DENTJODS.2020.83927.1061 PMid:33344683

62. Gonulol N, Ozer S, Tunc ES. Water sorption, solubility, and color stability of giomer restoratives. J Esthet Restor Dent. 2015;27(5):300-6. https://doi.org/10.1111/jerd.12119 PMid:25145876

63. Singla MG, Relhan N, Virdi I. Comparative evaluation of depth of cure of three high viscosity bulk fill composites versus conventional composite: An in vitro study. Int $\mathrm{J}$ Clin Prev Dent. 2018;14(2):145-51. https://doi.org/10.15236/ ijcpd.2018.14.2.145

64. Tsujimoto A, Barkmeier WW, Takamizawa T, Latta MA, Miyazaki M. Depth of cure, flexural properties and volumetric shrinkage of low and high viscosity bulk-fill giomers and resin composites. Dent Mater J. 2017;36(2):205-13. https://doi. org/10.4012/dmj.2016-131 PMid:28154317

65. Tarle Z, Attin T, Marovic D, Andermatt L, Ristic M, Tauböck TT. Influence of irradiation time on subsurface degree of conversion and microhardness of high-viscosity bulk-fill resin composites. Clin Oral Investig. 2015;19(4):831-40. https://doi.org/10.1007/ s00784-014-1302-6 PMid:25138041

66. Gayatri C, Rambabu T, Sajjan G, Battina P, Priyadarshini MS, 
Sowjanya BL. Evaluation of marginal adaptation of a selfadhering flowable composite resin liner: A scanning electron microscopic study. Contemp Clin Dent. 2018;9 Suppl 2:S240-5. https://doi.org/10.4103/ccd.ccd_156_18

PMid:30294151

67. Amaral FL, Colucci V, Palma-Dibb RG, Corona SA. Assessment of in vitro methods used to promote adhesive interface degradation:
A critical review. J Esthet Restor Dent. 2007;19(6):340-54. https://doi.org/10.1111/j.1708-8240.2007.00134.x

PMid:18005284

68. Chuenarrom C, Benjakul P, Daosodsai P. Effect of indentation load and time on Knoop and Vickers microhardness tests for enamel and dentin. Mat Res. 2009;2(4):473-6. https://doi. org/10.1590/S1516-14392009000400016

Author Queries???

AQ1: Kindly provide history details

AQ2: Kindly provide last accessed details 